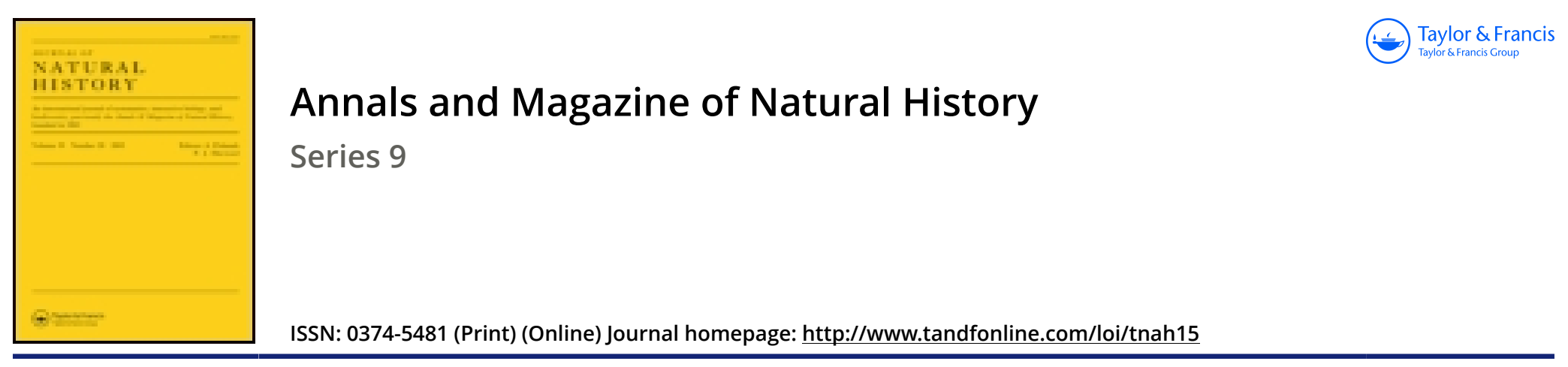

\title{
VIII.-Some new insular squirrels of the Callosciurus caniceps-concolor group from Peninsular Siam
}

\section{Oldfield Thomas \& Herbert C. Robinson}

To cite this article: Oldfield Thomas \& Herbert C. Robinson (1921) VIII._Some new insular squirrels of the Callosciurus caniceps-concolor group from Peninsular Siam , Annals and Magazine of Natural History, 7:37, 118-123, DOI: 10.1080/00222932108632492

To link to this article: http://dx.doi.org/10.1080/00222932108632492

曲 Published online: 02 Sep 2009.

Submit your article to this journal $₫$

Џll Article views: 3

Q View related articles $\sqsubset$ 
near the caudal margin; tergites three to five dull orange; six and seven black; eight and nine orange; sternites orange, segments six aud seven and the basal half of eight black. Male hypopygium with the ninth tergite about as in N. unicingulata, but the lateral angles not so pronounced; eighth sternite notched medially, fringed on either side with conspicuous yellow hairs.

Hab. Natal.

Holotype, $\delta$, Ulundi, altitude 5000-6500 feet, September 1896 (G. A. K. Marshall). B.M. no. 1903. 17.

Type in the collection of the Britisì Museum (Natural History).

Nephrotoma marshalli agrees with $N$. crocea (Loew) in its bitid frontal tubercle, but differs in the short antenne, the differently shaped occipital mark, and the details of coloration. It agrees well with $N$. unicingulata, Alexander, in the coloration of the abdomen and the macrotrichia of the wing, but differs in the structure of the frontal tubercle and the details of coloration and structure. This interesting crane-fly is respectfully dedicated to its collector, Dr. Guy A. K. Marshall.

\section{VIII.-Some new Insular Squirrels of the Callosciurus caniceps-concolor Group from Peninsular Siam. By Oljfield Thomas and Herbert C. Robinson.}

(Published by permission of the Trustees of the British Museum.)

THE following new forms of Squirrel come from various small islands off the west const of Peninsular Siam, between $9^{\circ}$ and $6^{\circ} \mathrm{N}$. latitude, the majority being from islets near Salanga (=Junk-Ceylon), $8^{\circ} \mathrm{N}$.

In describing them we are confronted with the difficulties every one has met in dealing with plastic island forms of various degrees of specialization, and the question as to what forms should have binomial and what trinomial is one that we have had great hesitation in deciding.

On the whole, in this group, we have come to the conclusion that the relationships of the different forms will be most casily understood if they are attached to what appear to be their parent continental species, and that of these it is advisable to recognize three, namely :-

C. caniceps, from north of about $13^{\circ}$, with yellow seasonally 
changing back, no epaulets or groin-patches, and with a black-tipped tail.

C. epomophorus, from between $13^{\circ}$ and $7^{\circ}$, greyish, with reddish epaulets and groin-patches, the tail black-tipped.

C. concolor, southwards of about $7^{\circ}$, grizzled grey, without epaulets or groin-patches, the tail-tip not prominently black.

Even between these intermediates may occur, but to combine the whole of the great number of local and nameable subspecies under one specific heading would in our opinion increase the already great difficulty of allocating the different forms to their respective groups. And we have even greater objection to the giving of binomial names to all.

The Mohea squirrels alone, as will be seen below, we have had to exclude from this arrangement.

With regard to the formation of names, it is obviously advisable to call local subspecies by terms which recall their localities; but unfortunately Malay names do not lend themselves to conversion into Latin terms without resulting in a most trying cacophony. We have therefore ventured to take certain liberties with the Malay words in order to reduce this cacophony to a minimum while still recalling the localities to which the new forms belong.

The series of specimens of these squirrels examined by us in Lundon is a selection, numbering four to six from each island, from those originally collected by Robinson and Kloss and the native collectors of the Federated Malay Sates Musoums, and amounting to many lundreds. Those now bronght liome, which form the basis of this joint paper, are all presented to the National Museum by the authorities of the Federated Malay States Musenms. Of most forms here described it may be assuned that something like twenty have been examined in Kuala Lumpur by Robinson, in addition to those brought home and now in Londen.

We commence with forms from the islands nearest to Salanga (Junk-Ceylon), where typical C. epomophorus occurs.

\section{Callosciurus epomophorus panjizs, subsp. n.}

Like epomophorus, but the ears, the underside of the wrists, and the hairs round the genital organs prominently whitish. On the ears the hairs are longer and are white nearly or quite to their bases, not merely grizzled black and white as in epomophorus. Upperside of fore feet also averaging whiter. Amount of rufous on neck, under surface, and base of tail about as in epomophorus.

For dimensions and designation of type, see tables on p. 123. 
Hah. Pulau Panjang, east of Salanga, $8^{\circ} 0^{\prime}$ to $8^{\circ} 7^{\prime}$. Type from Telok Pah.

Callosciurus epomophorus panjioli *, subsp. $\mathrm{n}$.

Like epomophorus in all respects, including the colour of ears and wrists, but the rufous of the neck-patches and sides more extended along the sides of the nape and shoulders, where they form a dull rufous suffusion. Midrib of tail averaging a little lighter below.

Hab. Pulau Panjang Anak, north of P. Panjang, $8^{\circ} 8^{\prime} \mathrm{N}$.

Although P. Panjang Anak is rather farther from Salanga than P. Panjang is, the squirrel there is the more like true epomophorus, but community of origin may in each case have been from the mainland to the north.

\section{Callosciurus epomophorus nakanus, subsp. $\mathrm{n}$.}

Specialized in the same direction as panjioli, but much further, the whole lateral area, from the sides of the neck over the shoulders to the sides of the hip, rich forruginous, about as in the brightest epaulet-patches of epomophorus. Crown and median dorsal area-which is narrowed between the ferruginous sides-strongly suffused with fulvous and grizzled superficially with buffy and black, very different. from the greyish of epomophorus. Ferruginous of under surface also greatly extended, the chin and chest alone grizzled fulvous greyish. Base of tail below ferruginous for $2-3$ inches; rest of tail more fulvous than usual, especially along its midrib subterminally.

Hab. Koh Naka, an islet between Salanga and the north part of Pulau Panjang, $8^{\circ} 4^{\prime} \mathrm{N}$.

\section{Callosciurus epomophorus mapravis, subsp. $\mathrm{n}$.}

A further development of the specializations of C.e.panjius, the upper surface quite as in that form, the ears and wrists similarly white. In addition, the chin, throat, and middle area of the belly are white or whitish, instead of grey, strongly contrasting with the ferruginous; the genital region is still more prominently white, and the forearms and hands are also whitish. Under surface of tail with the subterminal part of the midrib more or less fulvous.

Hab. Koh Maprau, between Salanga and the south end of Pulau Panjang, $7^{\circ} 58^{\prime} \mathrm{N}$. 


\section{Calloseiurus epomophorus pipidonis, subsp. $\mathbf{n}$.}

Size smaller than in epomophorus and the colour paler throughout. Upper surface uniformly suffused with buffy, not so dark a grey as in epomophorns; under surface with the rufous duller anteriorly and more ochraceous on the groinpatches.

Hab. Koh Pipidon, $7^{\circ} 45^{\prime} \mathrm{N}$.

\section{Callosciurus epomophorus tacopius, subsp. $n$.}

General colour above more suffused with fulvous than in epomophorus, especially along the shoulder-area. Below, this is even more strongly marked, the whole under surface more or less strongly ochraceous - the chest as usual least so and the inguinal region most, but there is only rarely a distinctly grey chest. A paler ochraceous postauricular patch. Ochraceous of belly running down to the heels.

Hab. Koh Rah, Takopah, coast of Peninsular Siam, $8^{\circ} 50^{\prime} \mathrm{N}$.

Specimens from a locality intermediate between this and Salanga, Tang Prang, Takuatung, $8^{\circ} 35^{\prime}$, appear to be quite similar to true epomophorus, and again others from Delisle Island, further north, do not seem to have become definably specialized.

Callosciurus concolor telibius *, subsp. $n$.

Size smaller than in the previous forms. Coloration very similar to that of Perak concolor, the back grizzled ochrnceous tawny or cinnamon instead of the grizzled grey of the epomophorus series. No trace of reddish epaulets or warmer areas over shoulders, nor of ferruginous side, groin, or tail patches. Below dull greyish clay-colour, nearly as in lancavensis, not so clear a grey as in concolor, the usual darker median line present but not conspicnons. Hands and feet grizzled grey as in coneolor, but the hairs of the terminal phalanx of both fingers and toes buffy yellow. Tail with black end as in all the epomophorus group, its upper surface grizzled, with buffy tips to the hairs; its midrib below (short of the black tip) prominently buffy for its terminal half.

Hab. Pulau Telibun, near the coast of Trang, Peninsular Siam, $7^{\circ} 18^{\prime} \mathrm{N}$.

In its possession of a black tail-tip this squirrel resembles

* The accent being on the middle syllable of 'Telibun, the above seems the best name to indicate that fict. 
epomophorus, but its general characters are distinctly those of concolor.

\section{Callosciurus moheius, sp. n.}

Size considerably smaller than in the ordinary members of the concolor-eaniceps group, but essential characters similar. General colour above deep buffy, without shoulder-patches. Small buffy postauricular patches present. Under surface greyish white, lighter on the chin and throat, darker on the belly, where there is a darkor median line; small groinpatches present, deep buffy. Front of forearms greyish white, hands and inner sides of forearms quite white; inner side of hind limbs white, hairs of terminal phalanges, both fore and hind, yellowish. Tail with a black tip, its remainder grizzled with black and buffy, the bases of the hairs buffy; midrib below bright buffy, short of the terminal black tip.

Hab. Pulau Mohea-north-about 30 miles off the Trang coast, $7^{\circ} 14^{\prime} \mathrm{N}$.

The small squirrels of Mohea we have made an exception to the general principle of attaching the insular forms to the parent continental species. Mohea being out to sea opposite the dividing-line between the ranges of epomophorus and conoolor, while its squirrel shows some unexpected resemblances to caniceps, and others to telibius (of which it might most naturally be supposed to be a derivative), we are at present unable to decide to which species it should be attached, and provisionally give it a binomial name.

But Mohea itself is divided into two by a channel some 70 yards in width, and, narrow as this is, it has resulted in the squirrels of the two islets being definably different from each other. Giving the primary name moheius to the form of the north islet, we propose to call that of the south-

\section{Callosciurus moheius mohillius, subsp. n.}

General essential characters, the small size, yellowish coloration, black tail-tip, and absence of ferruginous patches as in moheius, but the dorsal colour duller and browner, nearly approaching "clay-colour"; under surface also darker, against which the buffy groin-patches show more strongly. Postauricular patches searcely perceptible. Feet and tail as in moheius, though the midrib of the latter is not so strongly ochraceous.

Hab. Pulau Mohen-south-7 $7^{\circ} 13^{\prime}$ N. 
Dimensions of types :-

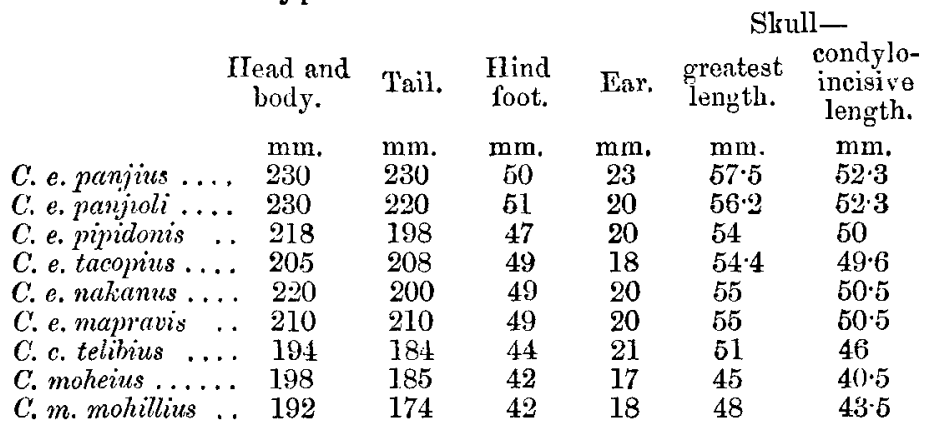

Types :-

B.M. no. Original no. Collected.

Of C. e.panjius. $\quad$ o ... 20.12.4.36. 246. 20th Jan., 1918.

C.e.panjioli. $\quad$ o $\ldots .20 .12,4.41 . \quad 435 . \quad 29$ th Jan., 1918.

C. e. pipidones. $\quad$ \& ... 20.12.4.53. 8135 . 3rd Feb., 1919.

C. e. tucopius. $\quad \delta^{*} \ldots$ 20. 12.4.56. 8239. 16th Feb., 1919 .

C.e.nakanus. o .... 20.12.4.43. 505. 4th Feb., 1918.

C. e. mapravis. O $\ldots$ 20.12.4.51. 591. 10th Feb., 1918.

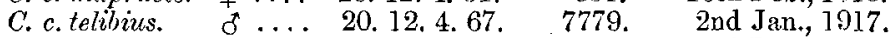

C. moheius. $\quad$ क .... 20.12.4.72. 8102. 2nd Feb., 1919.

C. m. mohillius. of ... 20. 12.4.75. 8112. 3rd Fub., 1919.

All presented to the National Museum by the authorities of the Federated Malay States Museums.

IX.-Descriptions of new Chalcidoid Flies from Coimbatore, South India. By S. A. RoHwer, Honorary Custodian of Hymenoptera, U.S. National Museum.

Ty e new species of Chalcidoid parasites characterised in the following pages belong to the Elasmidæe and Eulophida and were submitted for identification by Ramakrishna Ayyar, acting Government Entomologist, Madras Agricultural College, Coimbatore, India. The collection, of which the species here treated formed a part, contained certain other Hymenopterous parasites, for which a report enumerating all species, except those belonging to the two families mentioned above, has already been published by Mr. A. B. Gahan *. Much of the laboir connected with the identifying of the

* "Report on a small Collection of Indian Hymenoptera," Proc. U.S. Nat. Mus. vol. Ivi. no. 2299, pp. 513-524 (October 20, 1919). 